\title{
PREFERRED COMMUNICATION CHANNELS AMONG OMANI STUDENTS FOR ACADEMIC ADVISING
}

\author{
Bilal Khlaf Al.Omari ${ }^{1 *}$ and Anwar Mohamed Saqr ${ }^{1}$ \\ ${ }^{1}$ Al Buraimi University College, Sultanate of Oman
}

\begin{abstract}
Academic advising has gained more focus in contemporary research, literature, and policy so far, but it still faces several difficulties such as miss-communication with students. This paper explores the preferred communication channels among Omani students to contact their advisors to make the academic advising process more activated, flow, and efficient. For this purpose, 250 students at different levels at Al Buraimi University College have been selected randomly and were presented with a questionnaire about their perception towards the communication channels with academic advisors. Results indicated that face-to-face communication is a preferable method among students followed by email, social media, and phone calls.
\end{abstract}

Keywords: Academic advising; Student access; Communication channels

\section{Introduction}

The professional literature has repeatedly emphasized that the academic advising of students is a highly important issue to avoid academic failure. Student's decision to remain in college becomes a big challenge facing most of the countries. However, the studies which have been carried out so far have shown that contact with an academic advisor in higher education is a crucial factor in a student's decision to remain or leave the college. Academic advising is a plan outlay or process that is designed at enabling students to be in a position to approach and handle matters about education in a way that is well organized and meaningful to them (Cook, 1999). Advising students in bringing together all the students that might come up in the academic lives of students (Hughey, 2011).

Some of these matters might turn into being very complicated if an excellent advising model is not in place. Student's retention is one of the standard problems that have been identified in many colleges and universities; this has been contributed a lot to the population of students who have left schools (Heiserer, 2002). Other matters that have been reported include issues related to discipline, student performance, and the general student behaviours. These difficulties can be used to categorize students in schools, for instance, students can be classified as being academically at risk or academically safe students (Cejda, 2006).

Lack of adequate communication skills on the part of the advisor may also hinder the advising program in institutions (Poyrazli, 2002). These entail using the communication techniques which cannot lead to successful sharing of information between the advisor and the advisee. For instance, not paying attention to the students' queries by not addressing their questions properly and thinking of a response when the advisee is still talking (O’Bannon, 1994).

For that reason, the advisors should develop proper communication techniques like maintaining eye contact during the session and responding appropriately to advisee's questions. Finally, the advising programs should aim to promote the performances of the students and offer assistance in the correction of the students with severe behaviours which might lead to their poor performance (Crookston, 1972). New technological methods such as social media would be helpful in communicating with students. Some findings indicated that participants who used the electronic social networks might be beneficial for seeking help and were receptive to interacting with students (Paul \& Julie, 2013). An integrated E- academic advising system could help to solve the communication issue and would save the time for face-to-face (Amin \& Fekry, 2015). 
This paper explores the preferred communication channels among Omani students to contact their advisors to make the academic advising process more activated, flow, and efficient. In the next section, a literature review is introduced. Section 3 presents both questions and hypotheses of research. The methodology of this research is provided in Section 4. The results and the concluding remarks are included in Sections 5 and 6.

\section{Literature Review}

There is a considerable research literature on academic advising which has become an important process and prominently features in the modern education system world over. Academic advising has gained more focus in contemporary research, literature, and policy so far. Therefore, it is upon the learning institutions to come up with a well-designed and planned academic advising model as well as a good support program which can be used to address the demands of those students categorized as academic at-risk students (Haig, 2011).

The programs that are typically implemented in the educational institution mainly aim at boosting the school performance of these types of students by helping them to achieve their personal, academic and career targets or aims. They should also be aimed at resulting in the retention of the students in schools (Bierema, 2002). Therefore, all the academic institutions, for instance, universities should come up with an advising initiative that will adequately address the needs of these academic at-risk students. The advising model aims at reducing the academic cases like the poor performance of students which might result in their suspension (Broughton, 2001).

Some of the academic advising models that have been put in place to address these issues include; the prescriptive advising model which mostly concentrates on the relationship that exists between the advisor and the advisee based on the authority that entails handing down of the required advice. The development model builds on an equal relationship that exists between the advisor and the advisee (Broughton, 2001). It aims at promoting the personal growth of the student. The integrated advising model aims at addressing the shortcomings that exist in both developmental and prescriptive advising model. The last model is the intrusive advising model which recognizes the specific needs of the academic at-risk students (Bickel, 2005).

For instance, the model helps in reducing the issues involving discipline and performance of this kind of students. While trying to implement some of this kind of academic advising model, to be specific the intrusive advising model, the advisors have been going through various communication challenges which have been able to hinder the implementation of the advising programs in both colleges and universities (Moyer, 1999).

Some of these difficulties might have been originated from the advisors or the advisees. Some of the communication challenges that do affect the implementation of the advising programs in the institutions are as discussed below.

First, the disorganization of the advising sessions. It is true that the institutions may have been able to come up the relevant advising programs (Habley, 1986). Although these sessions have been planned, the problem is that sometimes the advisors do not allocate more time to enable students. The advisor needs to know the advisee's name, they sometimes don't have academic records of the students, and they even don't give them the required attention that can help solve the students' needs (Kolanko, 2006). The disorganization of the session has affected the implementation of the advising programs in institutions. Consequently, for some programmes which need to be implemented, the advisors need to organize their sessions in a manner that they get to know the students. Also, it is essential to have the relevant academic records for the students and be able to entirely give attention to the needs of the at-risk students in both universities and colleges (Lau, 2003).

Second, the external distractions also act as one of the significant communication challenges that affect the implementation of the advising programs in the institutions (Bardovi-Harlig, 1990). It is true that the institutions could be having the right and organized academic advising programmes, but the immediate surrounding might not be in a position to support this kind of programs (Campbell, 2007). These immediate environments do 
interfere with the exchange of thoughts between the advisor and the advisee. Some of these factors include; noise, the room temperatures, uncomfortable seating, and lighting. These mostly concern the advisors while the students' distracters include; using phones during the session and coming with friends to the advisory rooms (Gordon, 2011). Thus, the advisory rooms should be situated away from noisy places, and students should be advised to switch off their phones during the counselling sessions.

\section{Research Questions and Hypotheses}

1. Which ways are more effective for communication between Oman's students and their academic advisors?

2. Is there an association between independent demographic and educational variables and preferring communication ways?

3. This study hypothesized that:

4. $\mathrm{H}_{1}$ : Face-to-Face is the effective and preferred way of communication.

5. $\mathrm{H}_{2}$ : There is a relationship between the preferred communication way and some of the independent demographic and educational variables.

\section{Methodology}

This study used the inductive approach to explore and describe the effective communication ways between Oman's students and their academic advisors. This approach was used to generate a new theory based on concrete empirical evidence for inferencing and extracting abstract concepts and theoretical relationships (Bernard \& Bernard, 2012). However, the exploratory and descriptive research was conducted to increase our knowledge and gain a better understanding of a situation. Neuman (2011) pointed out that using these methods would help in obtaining a clear picture of the specific details of a situation such as a social setting and a relationship as it naturally occurs.

A 12-item questionnaire was randomly distributed to 250 students at AL Buraimi University College. The raw data of this questionnaire were analyzed using the Statistical Package for the Social Sciences (SPSTUDENTS), version 22. The questionnaire was structured and posed the questions articulated and directed for considering the validity of content, and eliminating the possibility of misinterpretations. It is clear that the reliability refers to the degree of consistency of the collected data to measure what it is supposed to measure by using Cronbach's alpha coefficient. Since that coefficient shows the degree to which all the items in a test measure the same attribute (Masitsa, 2011). Tavakol and Dennick (2011) mentioned that the reliability and validity are mandatory for accuracy to the interpretation of research data. The Cronbach alpha of this questionnaire was calculated and found to be 0.73 which is reasonable and feasible since an acceptable value must lie between 0.70 and 0.90 (Hof, 2012).

\section{Results}

From the all distributed questionnaires, 59\% were completed by the female while male totalled $41 \%$. Regarding participant's specialization 9\% of were done by the English students, followed by the information technology students with $16 \%$, then $34 \%$ are for Busines students and accounting, whereas the Law students did the $40 \%$. The participants were asked about their educational level, which is classified into four academic years; one, two, three and four. The results indicate that the majority of the participants in the $1^{\text {st }}$ year prefer face-to-face, followed by $3^{\text {rd }}$ year students with $60 \%$. During the $2^{\text {nd }}$ year, students have the total of $55 \%$ compared to the $37 \%$ in the $4^{\text {th }}$ year students. Most of the participants were in the first and second year. 
Table 1: Summary of Sample

\begin{tabular}{|c|c|c|}
\hline & Frequency & Percentage $\%$ \\
\hline \multicolumn{3}{|l|}{ Gender } \\
\hline Male & 103.00 & $41 \%$ \\
\hline Female & 147.00 & $59 \%$ \\
\hline \multicolumn{3}{|l|}{ Specialty } \\
\hline English & 23.00 & $9 \%$ \\
\hline Business students \& Accounting & 86.00 & $34 \%$ \\
\hline Law & 100.00 & $40 \%$ \\
\hline Information Technology & 41.00 & $16 \%$ \\
\hline \multicolumn{3}{|l|}{ Educational level } \\
\hline First Year & 96.00 & $38 \%$ \\
\hline Second Year & 116.00 & $46 \%$ \\
\hline Third Year & 30.00 & $12 \%$ \\
\hline Fourth & 8.00 & $3 \%$ \\
\hline \multicolumn{3}{|l|}{ Employment status } \\
\hline Employee & 60.00 & $24 \%$ \\
\hline Unemployed & 190.00 & $76 \%$ \\
\hline \multicolumn{3}{|l|}{ Marital status } \\
\hline Married & 68.00 & $27 \%$ \\
\hline Single & 182.00 & $73 \%$ \\
\hline \multicolumn{3}{|l|}{$\underline{\underline{A g e}}$} \\
\hline $18-20$ & 82.00 & $33 \%$ \\
\hline $20-22$ & 75.00 & $30 \%$ \\
\hline $22-24$ & 26.00 & $10 \%$ \\
\hline Over 24 & 67.00 & $27 \%$ \\
\hline \multicolumn{3}{|l|}{ Grade point average } \\
\hline Less than 1.5 & 7.00 & $3 \%$ \\
\hline $1.5-2$ & 49.00 & $20 \%$ \\
\hline $2-2.5$ & 59.00 & $24 \%$ \\
\hline $2.5-3$ & 73.00 & $29 \%$ \\
\hline Over 3 & 62.00 & $25 \%$ \\
\hline
\end{tabular}

As it is presented in Table 1, 24\% of the participants are employed, where the majority which makes the total of $76 \%$ is not. It also shows that $27 \%$ are married, while the majority which is $73 \%$ are single. The table indicated that $27 \%$, of participant's age, is between 18 to 24 and over 24 years respectively. The grade point average has been displayed in the survey. The results illustrate the grades of participants with $3 \%$ less than 1.5 . Moreover, $20 \%$ of the sample GPA is between 1.5 to 2.0. Moreover, $24 \%$ of them between 2.0 to 2.5. At the same time, the majority has 2.5 to 3 GPA, and the rest have GPA above 3 . 
Proceeding of the $4^{\text {th }}$ International Conference on Education, Vol. 4, Issue 2, 2018, pp. 16-24

Table 2: Percentages Distribution for Preferred communication channels of students

\begin{tabular}{|c|c|c|c|c|}
\hline & Face-to-Face & Email & Phone call & Social media \\
\hline \multicolumn{5}{|l|}{ Gender } \\
\hline Male & $60.2 \%$ & $11.7 \%$ & $13.6 \%$ & $14.6 \%$ \\
\hline Female & $62.6 \%$ & $18.4 \%$ & $3.4 \%$ & $15.6 \%$ \\
\hline \multicolumn{5}{|l|}{ Specialty } \\
\hline English & $52.2 \%$ & $13.0 \%$ & $13.0 \%$ & $21.7 \%$ \\
\hline Business\&Accounting & $79.1 \%$ & $8.1 \%$ & $1.2 \%$ & $11.6 \%$ \\
\hline Law & $52.0 \%$ & $14.0 \%$ & $15.0 \%$ & $19.0 \%$ \\
\hline Information Technology & $53.7 \%$ & $36.6 \%$ & $0.0 \%$ & $9.8 \%$ \\
\hline \multicolumn{5}{|l|}{ Educational level } \\
\hline First Year & $71.9 \%$ & $10.4 \%$ & $5.2 \%$ & $12.5 \%$ \\
\hline Second Year & $55.2 \%$ & $19.8 \%$ & $10.3 \%$ & $14.7 \%$ \\
\hline Third Year & $60.0 \%$ & $16.7 \%$ & $0.0 \%$ & $23.3 \%$ \\
\hline Fourth & $37.5 \%$ & $12.5 \%$ & $25.0 \%$ & $25.0 \%$ \\
\hline \multicolumn{5}{|l|}{ Employment status } \\
\hline Employee & $55.9 \%$ & $15.3 \%$ & $13.6 \%$ & $15.3 \%$ \\
\hline Unemployed & $63.7 \%$ & $15.8 \%$ & $5.8 \%$ & $14.7 \%$ \\
\hline \multicolumn{5}{|l|}{ Marital status } \\
\hline Married & $57.4 \%$ & $14.7 \%$ & $10.3 \%$ & $17.6 \%$ \\
\hline Single & $63.2 \%$ & $15.9 \%$ & $6.6 \%$ & $14.3 \%$ \\
\hline \multicolumn{5}{|l|}{ Age } \\
\hline $18-20$ & $57.3 \%$ & $23.2 \%$ & $3.7 \%$ & $15.9 \%$ \\
\hline $20-22$ & $70.3 \%$ & $9.5 \%$ & $5.4 \%$ & $14.9 \%$ \\
\hline $22-24$ & $46.2 \%$ & $15.4 \%$ & $19.2 \%$ & $19.2 \%$ \\
\hline Over 24 & $64.2 \%$ & $13.4 \%$ & $10.4 \%$ & $11.9 \%$ \\
\hline \multicolumn{5}{|l|}{ Grade point average } \\
\hline Less than 1.5 & $57.1 \%$ & $28.6 \%$ & $0.0 \%$ & $14.3 \%$ \\
\hline $1.5-2$ & $63.3 \%$ & $8.2 \%$ & $14.3 \%$ & $14.3 \%$ \\
\hline $2-2 . .5$ & $59.3 \%$ & $22.0 \%$ & $1.7 \%$ & $16.9 \%$ \\
\hline $2.5-3$ & $67.1 \%$ & $11.0 \%$ & $9.6 \%$ & $12.3 \%$ \\
\hline Over 3 & $56.5 \%$ & $19.4 \%$ & $6.5 \%$ & $17.7 \%$ \\
\hline \multicolumn{5}{|c|}{ Government sponsorship } \\
\hline Sponsored Student & $68.5 \%$ & $16.9 \%$ & $3.2 \%$ & $11.3 \%$ \\
\hline Non Sponsored Student & $54.8 \%$ & $14.3 \%$ & $11.9 \%$ & $19.0 \%$ \\
\hline \multicolumn{5}{|c|}{ Accommodation type } \\
\hline Internal & $71.7 \%$ & $13.3 \%$ & $5.0 \%$ & $10.0 \%$ \\
\hline External & $58.4 \%$ & $16.3 \%$ & $8.4 \%$ & $16.8 \%$ \\
\hline
\end{tabular}

Table 2 shows the preferred communication channels among students for academic advising. Approximately $60 \%$ of the male students and $62 \%$ of the females prefer face-to-face interviews with their academic advisor. In this regard, there is no significant difference between male and female for a face-to-face interview. On the other hand, $13 \%$ and $3 \%$ of male and female students respectively do prefer phone calls. Results for social media preferences are very close with only $1 \%$ difference between both of them.

It could be seen from Table 2 that $79 \%$ of Business and accounting students prefer face-to-face interview, whereas only $1 \%$ prefer a phone call. In contrast, None of IT students prefer a phone call. The preference for IT students is email communication with $36 \%$, and the social media reaches $9 \%$. At the same time, more than $20 \%$ of English students prefer the social media. Law students are like the others in term of preference as well as more than $50 \%$ prefer face-to-face but, there was no significant disturbance regarding email, phone call, and social media. 


\section{Communication Ways}

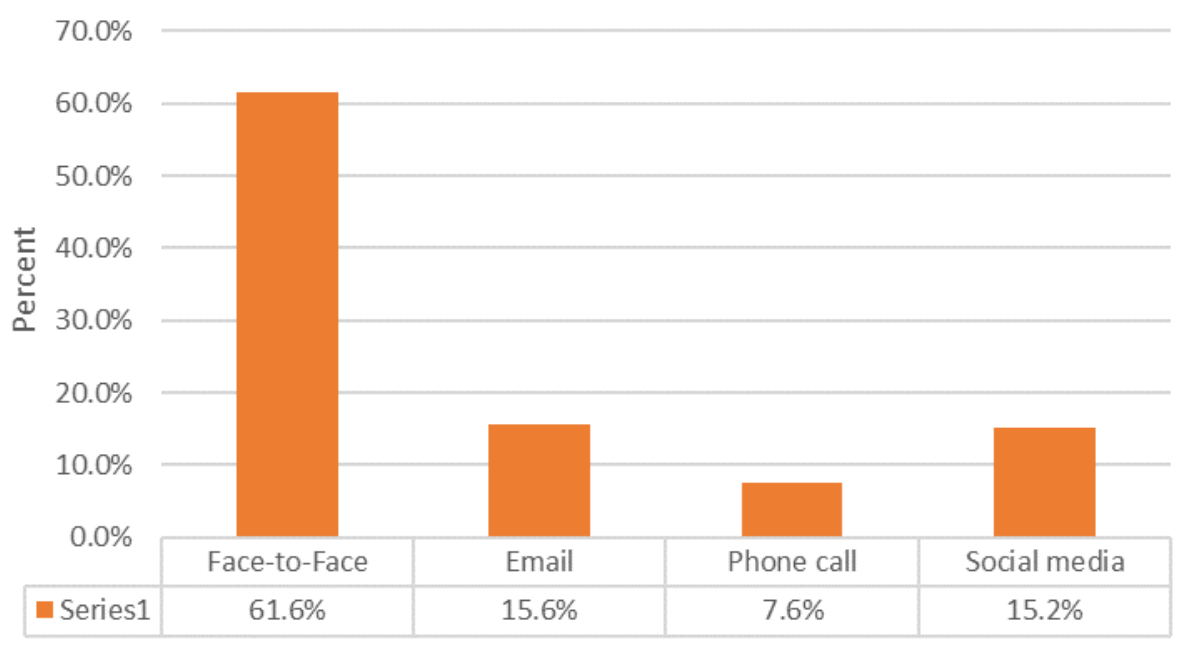

Figure 1: Graph of percentages distribution of preferred communication ways

Figure 1 shows that face-to-face communication is the preferable method between the single and married ones with $63 \%$ and $57 \%$ for each followed by social media for married students with $17 \%$ whereas emails are in the $2^{\text {nd }}$ position for the single students with $15 \%$. Phone calls, on the other hand, have the lowest rates among single students with only $7 \%$.

As it is represented, the face-to-face communication method is the most preferred one among the intact participants regardless students age, followed by an email with a vast difference. Social media and phone calls have both similar percentages among participants who are between 22 and 24 years old at a rate of $19 \%$ for both. However; phone calls have the lowest rates among all the communication method with only $3 \%$ just for the category of 18-20 and 5\% for the group of 20-22 years old which can be seen from table 2.

Table 2 also shows that the government-sponsored students show a tendency toward face-to-face communication with $68 \%$ followed by emails by $16 \%$, social media $11 \%$ and the phone calls with only $3 \%$. Although $54 \%$ of the non-sponsored students prefer face-to-face, social media ranked in the $2^{\text {nd }}$ place with $19 \%$ followed by emails with $14 \%$ and $11 \%$ for phone calls. Moreover, face-to-face as a channel of communication remains the preferred method between students with internal accommodation with almost $71 \%$ followed by $58 \%$ for students living in external housing. Phone calls also have the least percentages of only $5 \%$ and $8.4 \%$ for internal and external housing respectively. On the other hand, students in outer housing show a tendency toward the use of social media with $16 \%$ followed by emails with $16 \%$, whereas dorm accommodation students prefer e-mails with $13 \%$ over the use of the social media with only $10 \%$.

\section{Tests of Hypotheses}

The goodness-of-fit test was conducted to test whether there were significant differences between percentages of the preferred communication ways. The results are shown below in Table 3(a,b), where the null hypothesis was rejected since the p-value $<0.05$. Therefore, there is a significant difference between percentages of the preferred communication ways. Hence, face-to-face is the preferred way for communication between Omani students and their academic advisors because it has the highest percentage compared with others. 
Table 3(a,b): Results of goodness-of-fit

(a)

\begin{tabular}{|c|c|c|c|}
\hline & Observed $\mathrm{N}$ & Expected N & Residual \\
\hline Face-to-Face & 154 & 62.5 & 91.5 \\
\hline Email & 39 & 62.5 & -23.5 \\
\hline Phone call & 19 & 62.5 & -43.5 \\
\hline Social media & 38 & 62.5 & -24.5 \\
\hline Total & 250 & & \\
\hline
\end{tabular}

(b)

\begin{tabular}{|l|l|}
\hline Chi-Square & $182.672^{\mathrm{a}}$ \\
\hline df & 3 \\
\hline Asymp. Sig. & $\mathbf{. 0 0 0}$ \\
\hline
\end{tabular}

To test whether there is a significant relationship between the preferring communication ways, and independent demographic and educational variables, Chi-square test was conducted. Table 4 presented the results of ChiSquare test for the relationship between communication way and independent variables. It reveals that there is a relationship between the preferred communication way and gender, specialty, and government sponsorship since the P-values $<0.05$. While there is no relationship between preferred communication way and education level, employment status, marital status, age, and grade point average, where the $\mathrm{P}$-values $>0.05$. Therefore, the null hypothesis was rejected and accepted the alternative hypothesis that stated that there is a relation between the preferred communication ways and some of demographic and education variables. 
Table 4: Show the results of Chi-Square test for the relationship between communication way and independent variables

\begin{tabular}{|l|l|l|l|}
\hline \multirow{2}{*}{} & \multicolumn{3}{|l|}{ Dependent Variable: Communication Ways } \\
\hline Independent Variables & $\begin{array}{l}\text { Value of } \\
\text { Chi-Square Tests }\end{array}$ & df & $\begin{array}{l}\text { Asymp. Sig. } \\
\text { (2-sided) }\end{array}$ \\
\hline Gender & $10.131^{\mathrm{a}}$ & 3 & .017 \\
\hline Specialty & 40.437 & 9 & .000 \\
\hline Education Level & 15.877 & 9 & .069 \\
\hline Employment status & 4.103 & 3 & .251 \\
\hline Marital Status & 1.581 & 3 & .664 \\
\hline Age & 15.482 & 9 & .079 \\
\hline Grade Point Average & 13.766 & 12 & .316 \\
\hline $\begin{array}{l}\text { Government } \\
\text { sponsorship }\end{array}$ & 10.878 & 3 & .012 \\
\hline Accommodation Types & 3.665 & 3 & .300 \\
\hline
\end{tabular}

\section{Conclusion}

There are some noticeable dramatic changes in the educational delivery systems, student access, and faculty roles aiming to increase student retention and solve the student success problem. One of these changes is the academic advising which has become an important process and prominently features in the modern educational system world over. Indeed, academic advising has gained more focus in contemporary researchers, literature, and policies so far, but it still faces several difficulties such as miss-communication with students.

Models of academic advising have varied from, prescriptive, development, intrusive and integrated. Each one of them tries to address issues related to academic advising. Scholars have indicated that some of the communication challenges that might affect the implementation of the advising programs could be the disorganization of the academic sessions, time allocated for advising, the academic records and the distraction issues.

This study focused on exploring the preferred communication channels among Omani students to contact their advisors. It concluded that face-to-face communication was still the preferred method among Omani students to contact their advisors, followed by email, social media, and phone calls respectively. However, this study also concluded that there was a relationship between the preferred communication method and gender, specialty and sponsorship. However, this study recommended that more efforts should include more data and more work of the scholars and advisors which should be aligned together for exploring the best-preferred communication methods to handle the academic advising issues. Also, it would be manifest to explore which academic advising method is preferable for students.

\section{References}

Cook, S. (1999). A chronology of academic advising in America. The Menter: An AcademicAdvising Journal. Retrieved Februry, 2017.

Hughey, J. K. (2011). Strategies to enhance interpersonal relations in academic advising. NACADA journal, 31(2), 22-32 
Heisserer, D. L., \& Parette, P. (2002). Advising at-risk students in college and university settings. College student journal, 36(1).

Cejda, B. D., \& Leist, J. (2006). Challenges facing community colleges: Perceptions of chief academic officers in nine states. Community college journal of research and practice, 30(3), 253-274.

Poyrazli, S., Arbona, C., Nora, A., McPherson, R., \& Pisecco, S. (2002). Relation between assertiveness, academic self-efficacy, and psychosocial adjustment among international graduate students. Journal of college student development.43(5),632-640

O'Banion, T. (1994). An academic advising model. NaCADA Journal, 14(2), 10-16.

Crookston, B. B. (2009). A developmental view of academic advising as teaching. NACADA journal, 29(1), 7882.

Amador, P., \& Amador, J. (2014). Academic advising via Facebook: Examining student help seeking. The Internet and Higher Education, 21, 9-16.

Noaman, A. Y., \& Ahmed, F. F. (2015). A new framework for e academic advising. Procedia Computer Science, 65, 358-367.

Haig, J., MacMillan, V., \& Raikes, G. (2011). Human sexuality in a world of diversity. Nelson Education.

Bierema, L. L., \& Merriam, S. B. (2002). E-mentoring: Using computer mediated communication to enhance the mentoring process. Innovative Higher Education, 26(3), 211-227.

Broughton, E., \& Neyer, M. (2001). Advising and counseling student athletes. New directions for student services, 2001(93), 47-53.

Bickel, J., \& Brown, A. J. (2005). Generation X: Implications for faculty recruitment and development in academic health centers. Academic Medicine, 80(3), 205-210.

Moyer, A., Salovey, P., \& Casey-Cannon, S. (1999). Challenges facing female doctoral students and recent graduates. Psychology of Women Quarterly, 23(3), 607-630.

Habley, W. (1986). Show us the future: The challenges facing academic advising. NACADA Journal, 6(2), 5-11.

Kolanko, K. M., Clark, C., Heinrich, K. T., Olive, D., Serembus, J. F., \& Sifford, K. S. (2006). Academic dishonesty, bullying, incivility, and violence: Difficult challenges facing nurse educators. Nursing Education Perspectives, 27(1), 34-43.

L.K.Lau.(2003 "Institutional factors are affecting student retention," Education-Indianapolis then Chula Vista.124(1)126-136.

Bardovi-Harlig, K., \& Hartford, B. S. (1990). Congruence in native and nonnative conversations: Status balance in the academic advising session. Language learning, 40(4), 467-501.

Campbell, JP and Oblinger, DG.(2007). Academic analytics. EDUCAUSE Review. 42(4),40-57.

Gordon, V. N., Habley, W. R., \& Grites, T. J. (Eds.). (2011). Academic advising: A comprehensive handbook. John Wiley \& Sons.

Bernard, H. R. (2012). Social research methods: Qualitative and quantitative approaches Sage Publications.

Newman, W. L. (1991). Social research methods: Qualitative and quantitative approaches. Allyn and Bacon.

Masitsa, M. G. (2011). Exploring safety in township secondary schools in the Free State province. South African Journal of Education, 31(2).

Tavakol, M., \& Dennick, R. (2011). Making sense of Cronbach's alpha. International journal of medical education, 2, 53.

Hof, M. (2012). Questionnaire Evaluation with Factor Analysis and Cronbach's Alpha An. 